[Frontiers in Bioscience, Elite, 8, 427-435, June 1, 2016]

\title{
Genes associated with T helper 17 cell differentiation and function
}

\author{
Ayten Nalbant ${ }^{1}$, Doga Eskier ${ }^{1}$ \\ ${ }^{1}$ Izmir Institute of Technology, Department of Molecular Biology and Genetics, Molecular Immunology and \\ Gene Regulation Laboratory, Urla, Izmir, 35430 Turkey
}

\section{TABLE OF CONTENTS}

\section{Abstract}

2. Introduction

3. Lineage specification of Th17 cells

3.1. The retinoic acid-related orphan receptors (RORs)

3.2. Interferon-inducible factor-4 (IRF4)

3.3. B-cell activating transcription factor (BATF)

3.4. Runt-related transcription factor 1 (RUNX1)

3.5. FOXP3 and T-BET

3.6. Signal Transducer and Activator of Transcriptions (STATS)

4. Summary and perspectives

5. Acknowledgements

6. References

\section{ABSTRACT}

Interleukin-17 (IL-17)-producing $\mathrm{T}$ helper cells (Th17 cells) constitute a lineage of CD4 effector $\mathrm{T}$ helper cells that is distinct from the Th1 and Th2 CD4 phenotypes. In humans, Th17 differentiation is induced in the presence of the cytokines IL-1 beta, IL- 6 and TGF beta, whereas IL-23 maintains Th17 survival. Effector human Th17 cells express several cytokines and cell surface markers, including IL-17A, IL-17F, IL-22, IL-26, CCR6 and TNF $\alpha$. Studies on human cells have revealed that the RORC2 transcription factor plays an effective role in Th17 differentiation. Th17 cells contribute to the host immune response by involving various pathologies, including rheumatoid arthritis, multiple sclerosis and Crohn's disease. However, the full extent of their contribution to diseases is being investigated. The differentiation of Th17 cells is controlled by many transcription factors, including ROR gammat, IRF4, RUNX1, BATF, and STAT3. This review covers the general principles of CD4 T helper differentiation and the known transcription factors that play a role in the recently discovered Th17 cells.

\section{INTRODUCTION}

CD4 T cells are accepted as important actors in immune responses due to their capacity to regulate and coordinate other cells of the immune system. Because they are major players in the immune response, the characterization of these cells is crucial. Upon antigenic stimulation, naive CD4 T cells activate, proliferate and differentiate into different effector helper $\mathrm{T}$ cell subsets referred to as T helper (Th) 1 and Th2 $(1,2)$. These T cell subsets are characterized by their distinct cytokine production profiles and effector functions and carry their own specific, distinctive and heritable markers.

Interferon-gamma is the signature cytokine produced by Th1 cells and is responsible for immunity against intracellular pathogens. In addition, Th1 cells express genes associated with cytotoxicity, such as the Fas ligand and granzymes. Uncontrolled Th1 responses against self-antigens can lead to the development of autoimmunity. Th1 cells are generated from naïve $T$ helper cells by $T$ cell receptor (TCR) engagement and Signal Transducer and Activator of Transcription 1 (STAT1) signaling, which are induced by the IFNinduced activation of the IFN $\gamma$ R. Phosphorylated STAT1 induces the expression of transcription factor T-bet, which drives Th1 differentiation by trans-activating the Th1 signature cytokine IFN-gamma and the specific subunit of the receptor for interleukin (IL)-12, IL-12R $\beta 2$. Thus, the cell becomes responsive to IL-12, which is produced by activated antigen-presenting cells (APCs), and subsequent IL-12 signaling through Signal Transducer and Activator of Transcription 4 (STAT4) further stabilizes the Th1 phenotype. IL-4, IL-5 and IL-13 are secreted by Th2 cells, which play important roles in clearing extracellular pathogens and mediating allergic responses (3-7).

A distinct subset of CD4 $T$ cell effectors was recently identified and named $\mathrm{T}$ helper 17 cells (Th17) because these cells produce the cytokine IL-17 (Harrington et al., 2005, Park et al., 2005). Th17 cells 


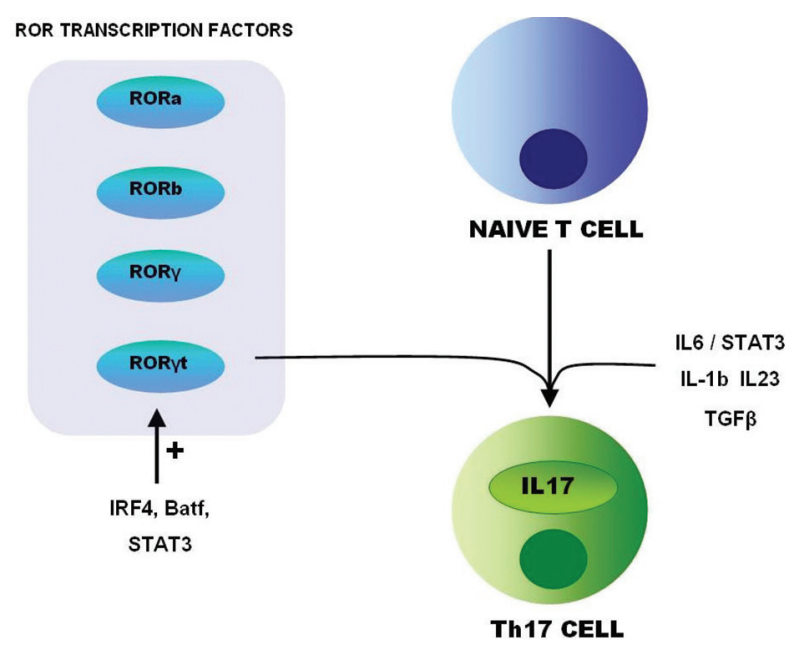

Figure 1. Th17 differentiation. Different members of the ROR family play differing roles in various cellular niches. RORC2 is one of the cytokines required for Th17 differentiation from naive T cells. RORC2 partners with various proteins to affect Th17 differentiation and is positively regulated by a number of factors. IRF4, BATF and STAT3 positively regulate RORC2, which partners with IL-6, STAT3, IL-1b, IL-23 and TGFb to form the interleukin 17 producing Th17 cells.

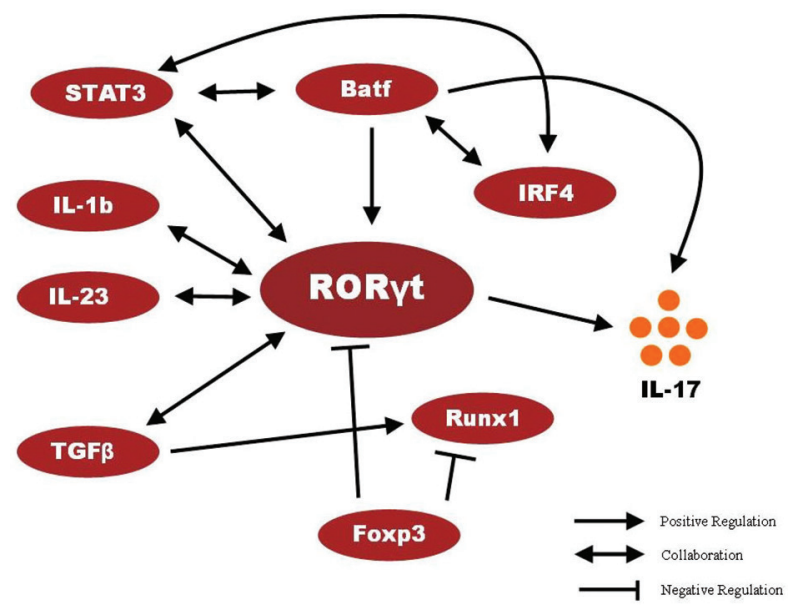

Figure 2. Networking of transcription factors involved in the Th17 differentiation. Most factors regulate differentiation through collaboration (indicated by double-headed arrow), while some regulate the expression or activity of others either positively (unilateral arrow) or negatively (bluntheaded line). Production of IL-17 is the main trait of Th17 cells, which is mainly upregulated by RORC2 and BATF. FOXP3 is known to inhibit RORC2 and RUNX1, while the remaining proteins either collaborate with each other or positively regulate others to drive IL-17 production in Th17 cells.

also produce the cytokines IL-17A, IL- 17F and IL-22 (Annunziato et al., 2007, Wilson et al., 2007) and the chemokine receptor CCR6 (Acosta-Rodriguez et al., 2007b, Annunziato et al., 2007, Hirota et al., 2007, Lim et al., 2008, Singh et al., 2008). Th17 differentiation is directed by lineage-specific transcription factors, including RORyt (or RORC) and ROR $\alpha$, and is controlled by the coordinated activity of a series of positive and negative regulators $(8-10)$.

\section{LINEAGE SPECIFICATION OF TH17 CELLS}

\subsection{The retinoic acid-related orphan receptors (RORs)}

ROR is a nuclear receptor containing an $\mathrm{N}$-terminal domain, a DNA-binding domain, a hinge region, a ligand-binding domain and a C-terminal region. In most nuclear receptors, ligand binding to the ligandbinding domain induces a conformational change, recruits transcriptional co-activators and starts the transcription process. The ROR family has three members: ROR $\alpha$, $\mathrm{ROR} \beta$ and ROR $\gamma$ (or RORC). Two different forms of $\mathrm{ROR} \gamma, \mathrm{ROR} \gamma$ and ROR $\gamma \mathrm{t}$ (or RORC2), are present in mammalian cells, and the only difference between there isoforms is the $\mathrm{N}$ terminus. ROR $\gamma \mathrm{t}$ is sufficient for IL-17 expression as well as Th17 cell differentiation from human CD4 T cells. RORyt functions with IL6/STAT3, TGF $\beta$, IL-1 $\beta$ and IL-23 to generate Th17 cells. IL-23 and RORgt provide Th17 mediated immunity. Several transcription factors, such as IRF4, BATF, STAT3 and E3 deubiquitinase USP17, control Th17 differentiation by positively regulating RORC expression (11-15).

Foxo1 inhibits RORyt activity through the T cell intrinsic binding of its DNA binding domain, whereas inverse agonists and antagonists (such as TMP778) of RORyt, as well as siRNAs specific to Rorc, have further helped characterize the role of RORyt in Th17 differentiation (16-19).

In addition to the ROR family of receptors, Th17 cells express several other receptors for the differentiation or recognition of other immune cells as well as target tissues. Of these receptors, the following are considered crucial: IL-6R, IL-23R and the TNF receptor CD120a, which are responsible for the initial differentiation mechanisms of Th17 cells, as well as IL-22R, which uses the IL-22 produced by the differentiated cell as its ligand and plays a role in the maintenance of the Th17 phenotype (20-22).

\subsection{Interferon-inducible factor-4 (IRF4)}

Mammalian interferon regulatory factor (IRF) members play many roles in the immune system, including the regulation of $\mathrm{T}$ cell differentiation. IRF4 binds weakly to DNA, and its expression is restricted to immune cells. IRF4 needs cofactors to stably bind DNA. In B cells, the binding of PU.1 to DNA facilitates the recruitment of IRF4. In IL-21 treated B cells, IRF4 interacts with STAT3. Irf4 ${ }^{-1-}$ CD4-positive T cells exhibit a failure in STAT3 binding and form defective $T$ follicular helper cells (Tfh). IRF4 can interact with Batf (the ATL-like basic leucine zipper transcription factor)-Jun complex to control transcriptional regulation (23-26). 


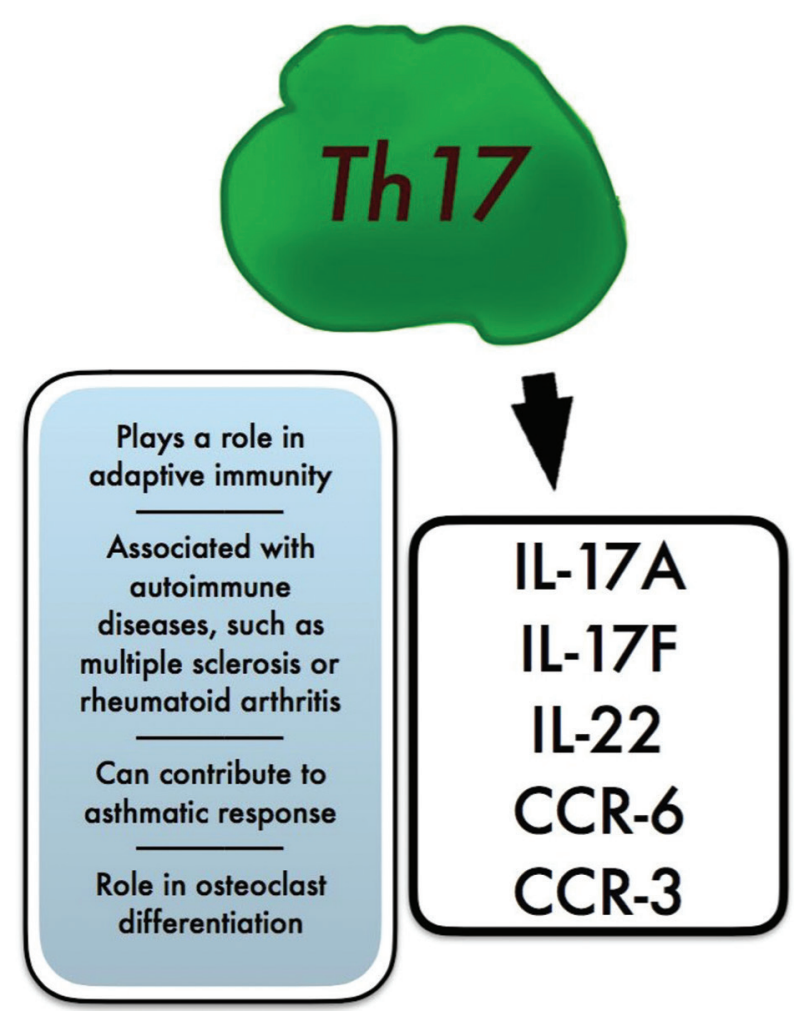

Figure 3. Differentiated interleukin-17 producing T helper (Th17) cells fill important niches in the immune system. The key cytokines produced by Th17 cells are interleukin (IL) 17A, IL-17F, IL-22 and CCR6.

IRF4 aids Th17 cell differentiation and is required for the induction of ROR $\gamma$ t and ROR $\alpha$. RhoA-associated kinase (ROCK) 2 is activated under Th17 polarizing conditions and phosphorylates IRF4, which directly binds to IL-17A and IL-21 promoters, inducing their transcriptional activation. The gene expression of IRF4 is induced by IL-1beta, which prompts a 5.4-fold increase in expression, and by IL-6, which results in a 5.5-fold increase in expression. There is a positive relationship between IRF4 and IL-17A gene expression, indicating that IRF4 plays an important role in human Th17 cell differentiation [2-6-7]. IL-6 mainly activates STAT3 through the JAK-STAT pathway. STAT3 binds to the promoters of various genes, such as RORC, IL-17, IL-17F and IL-21, and interacts with the BATF, IRF4 and c-MAF genes. These transcriptional factors are important for Th17 cell differentiation (23-26).

\subsection{B-cell activating transcription factor (BATF)}

BATF is a basic leucine zipper transcription factor of the activator protein-1 (AP-1) family that helps generate Th17 cells. BATF is required for the generation of $\mathrm{T}$ follicular helper (Tfh) cells but not Th1 cells and Treg cells. BATF interacts with IRF4 for the generation of Th2 and Th17 cells and is involved in the induction of the
IL-10, IL-17alpha and IL-21 genes in T cells. As a result, IL-6 activates the function of the BATF/IRF4 complex. Previous research has shown that IRF4 is activated upon IL-1 signaling and is critical for early Th17 cell differentiation. IRF4 interacts with NFATp (nuclear factor of activated T-cells) to induce IL-4 expression, suggesting that IRF4 modulates NFATp-dependent IL-2 expression, which is related with IL-17 production (27-30).

During the process of Th17 differentiation, BATF and RORyt directly attach to the promoter of the IL17 gene and induce its transcription in a synergistic manner. However, it has been observed that Th cells lacking BATF fail to differentiate to Th17 cells, despite the presence of ROR $\gamma \mathrm{t}, \mathrm{ROR} \alpha$ and IL-6. In addition to these findings, the function of BATF in Th17 differentiation remains unclear (27-30).

\subsection{Runt-related transcription factor 1(RUNX1) \\ Runt-related transcription factor 1 (RUNX1),} which is also known as acute myeloid leukemia 1 protein (AML1) and core binding factor subunit alpha-2 (CBFA2), is a protein encoded by the RUNX1 gene in humans. Transforming growth factor-beta (TGF $\beta$ ) induces the expression of the Runx related transcription factors RUNX1 and RUNX3 in CD4-positive T cells. This induction is required for the binding of RUNX1 and RUNX3 to RUNX binding sites in the FOXP3 promoter. Runx proteins form transcriptional complexes with Foxp3, RORyt and $\mathrm{T}$ bet (inhibitor of ROR $\gamma$ gene expression) to carry out Th differentiation and cytokine production. Runx1 induces RORyt expression and is required for the differentiation of Th17 cells and for Foxp3 function. The binding of ROR $\gamma$ t and Runx1 together to the IL-17 $\alpha$ locus leads to increased expression of IL-17. The Runx1 and Runx 3 transcription factors induce the differentiation of both Th1 and Th17 cells depending on the Runx interacting partner (Th1 and Th17 cell transcription factors, respectively). However, Foxp3 prevents both Runx1 and RORgt activity. Runx1 can modify RORyt/Foxp3 complexes and differentially associates with RORyt or Foxp3, thus regulating or repressing transcriptional activity depending on the specific cytokine interactions (31-34).

Both Runx1 and Runx3 maintain high levels of Rorc expression in Th17 cells. The Runx transcription factors are weak transcriptional factors that interact with other transcription factors to activate or repress gene expression. If the concentration of Runx1 is sufficiently high to form both the Runx1-T-bet and Runx1-RORyt transcription complexes, a $\mathrm{T}$ helper cell can simultaneously express IFN $\gamma$ and IL-17A. The overexpression of Runx1 or Runx3 in Th17 cells results in the induction of Stat 4 and Tbx21, which are downstream factors of IL12 signaling. Runx1 is a stronger activator of the Tbx21 and Stat4 genes than Runx3, resulting in higher amounts of IFN $\gamma$ producing cells. Both Runx1 and Runx3 maintain high Rorc expression 
Table 1. Genes and interactions in Th17 function and differentiation

\begin{tabular}{|c|c|c|c|c|}
\hline Gene name & Role in Th17 & Role in immune system & Associations with other proteins & References \\
\hline BATF & & & Induces IL-17 transcription & 27,30 \\
\hline CCR6 & Surface expression factor & $\begin{array}{l}\text { Associated with colorectal } \\
\text { cancer and Crohn's disease }\end{array}$ & Chemokine receptor & $8,9,10$ \\
\hline Foxo1 & & & Inhibits the RORC program & 16 \\
\hline Foxp3 & & & Antagonizes ROR production by Th17 & 39 \\
\hline IL-17A & Defining gene of Th17 & $\begin{array}{l}\text { Recruits monocytes and } \\
\text { neutrophils to inflammation site }\end{array}$ & Induced by IL-22 & $8,9,10$ \\
\hline IL-17F & & Pro-inflammatory role in asthma & IL-17RA and IL-17RC as receptors & $8,9,10$ \\
\hline IL-1beta & & & Induces expression of IRF4 & 24 \\
\hline IL-22 & & $\begin{array}{l}\text { Adaptive innate immune } \\
\text { response }\end{array}$ & IL-22R1 and IL-10R2 complex as receptor & 9 \\
\hline IL-23 & & Cytokine expression & & 14 \\
\hline IL-26 & & & Induces rapid phosphorylation of STAT3 & 39 \\
\hline IL-6 & & Cytokine expression & Activates STAT3 & 14 \\
\hline TGFbeta & & & Reciprocal relationship between TGFbeta and Foxp3 & $5,6,7,8,39$ \\
\hline IRF4 & & & Induces RORgammat, RORalpha, IL-17A, IL-22 & 23,24 \\
\hline RORyt & $\begin{array}{l}\text { Master regulator transcription } \\
\text { factor }\end{array}$ & & & 11,13 \\
\hline RUNX1 & & & Binds to RORgammat, Foxp3 and T-bet & $31,32,33$ \\
\hline STAT3 & STAT regulator of Th17 cells & & Controls transcription of Th17 differentiation & $44,45,46,47$ \\
\hline TNFa & Th17 cytokine & $\begin{array}{l}\text { Involved in systemic } \\
\text { inflammation }\end{array}$ & & 46 \\
\hline USP17 & & & Positively regulates RORC expression & 15 \\
\hline
\end{tabular}

despite increased expression of Tbx21 and Stat4 (inhibitors of the Rorc gene) (31-34).

\subsection{FOXP3 and T-BET}

Th17 and Treg cells exhibit a close, reciprocal relationship through the molecules TGF $\beta$ and FOXP3 (forkhead box P3). TGF $\beta$ induces Treg differentiation and collaborates with or regulates proteins in the Th17 differentiation pathway, whereas the Foxp3 produced by Treg cells antagonizes the ROR $\gamma$ t and ROR $\alpha$ produced by Th17 cells. In addition, retinoic acid causes the preferential differentiation of Treg over Th17 cells because it enhances TGF $\beta$ and inhibits IL- 6 receptor expression. Furthermore, the transcription factor hypoxia inducible factor 1-alpha (HIF1alpha) enhances ROR $\gamma \mathrm{t}$ expression and inhibits Foxp3 expression, which leads to the preferential differentiation of Th17 cells compared with Treg cells. These findings show that the immune system has mechanisms that can induce suppression or inflammation as desired, but the implications of this conclusion are not known yet (35-39).

Th1 specific $T$ box transcription factor (T-bet) exerts an indirect antagonistic effect on Th17 differentiation by blocking Runx 1 from binding and activating the RORC gene, which encodes the ROR $\gamma \mathrm{t}$ protein required to activate $\mathrm{IL}-17$. Runx1 and T-bet interact during the early Th17 cell differentiation process. However, this interaction mutually prevents both proteins from activating their target genes, resulting in an equal amount of each protein completely inhibiting the other's function in the differentiation process. A higher amount of Treg favors Th1 differentiation, whereas a lower amount favors Th17 differentiation. T-bet can also bind to a protein binding element in the RORC promoter, preventing Runx 1 from binding to its own adjacent binding site. It is unknown whether similar adjacent binding sites exist in other Runx1-activated genes, indicating that further investigation is required to understand the details and specificity of the repression mechanism (40-42).

\subsection{Signal transducer and activator of transcriptions (STATs)}

Signal transducer and activator of transcription 3 (STAT3) is a transcription factor that is activated by the cytokines IL-17, IL-23, IL-6 and IL-21. The importance of STAT3 has been shown by the finding that the 
deletion of STAT3 in T cells leads to the prevention of Th17 differentiation. STAT3 directly binds the IL-17 promoter, as was shown by a ChIP assay. STAT3 binds to enhancers and promoters of genes that are responsible for Th17 specification. STAT3 binds not only to the IL-17 promoter but also to the IL-21, IL-21r and IL-23r genes. The important role of STAT3 is the control of transcription factors involved in Th17 differentiation, such as IRF4, RORyt and Batf. STAT3 also plays an interesting role involving Th17 proliferation and survival. It was recently shown that the phosphorylation status of Smad2/Smad3 allows them to act as opposite cofactors of STAT3, which regulates Th17 differentiation through RORyt (43-47).

STAT proteins affect Th17 differentiation in a positive manner but can also affect this process in a negative manner. STAT1, which is activated by IL-23, plays an important role in Th17 differentiation. Th17 differentiation is inhibited in the absence of STAT1 (48). Another negative regulator of Th17 differentiation is STAT4, which is activated by IL-12 and acts as a positive regulator of Th1 differentiation and INF $\gamma$ production. The production of IL-17 is suppressed by IL-2 and IFN $\gamma$ (49). IL 2 activated STAT5 is involved in Treg and Th17 differentiation (50).

\section{SUMMARY AND PERSPECTIVE}

A distinct subset of CD4 $\mathrm{T}$ cell effectors denoted $\mathrm{T}$ helper 17 cells was recently identified. Th17 cells contribute to the host immune response by involving various pathologies, including multiple sclerosis, Crohn's disease and rheumatoid arthritis. The differentiation factors of Th17 cells in humans remain under investigation. An increasing body of evidence in the literature emphasizes that human CD4 T cells have a huge capacity to display plasticity during the differentiation of the T helper phenotype. Th17 cells can differentiate into Th1 and Th2 phenotypes, whereas FoxP3-positive Tregs can differentiate into Th1, Th2 and Th17 cells. Therefore, it is important to fully understand the differentiation mechanisms of $\mathrm{T}$ helper cells.

$\mathrm{T}$ helper 17 cells can express more than one master transcription factor. The interactions of transcription factors with other transcription factors and/or regulatory factors need to be further studied in detail. For example, BATF transcription factor expression is not limited to Th17 cells; in fact, this transcription factor can be expressed by all $\mathrm{T}$ helper cells, even though its role in other Th cells remains unclear. In addition to RORs, IRF4 and RUNX1, peroxisome proliferator activated receptor gamma (PPAR $)$ (51) and epidermal fatty acid binding protein (E-FABP) (52) have been shown to play a role in IL17 gene expression. However, the molecular mechanism underlying these regulations is not fully understood. Furthermore, it is also important to obtain a more in-depth understanding of the epigenetic regulation of T helper cells in order to comprehend the plasticity and stability of $\mathrm{T}$ helper cells.

Although the transcription factor RORC2 has been shown to be expressed in human Th17 cells, the relationships of $\mathrm{RORC}$ with other transcription factors remain unclear. It has been proposed that microRNAs in addition to cytokines and transcription factors can also play a role in $\mathrm{T}$ helper differentiation. Therefore, the roles of microRNAs in Th17 differentiation need to be clearly elucidated. MicroRNAs (miRNAs) are 17- to 23-nt RNA molecules that regulate the expression of protein-coding genes. It is very likely that induced or suppressed miRNAs regulate key transcription factors and other genes involved in $\mathrm{T}$ helper cell differentiation. Understanding the molecular mechanisms underlying Th17 cell differentiation and the regulation of this process will help scientists develop better therapeutic approaches for the treatment of Th17 cell-driven pathologies.

\section{ACKNOWLEDGEMENTS}

Research in the Dr. Nalbant's laboratory is supported by grants from the Scientific and Technological Research Council of Turkey (TUBITAK; Project\# 110T412 and $113 Z 362$ to Dr. Ayten Nalbant). The funders had no role in the study design, data collection and analysis, decision to publish, or preparation of the manuscript. The authors do not have any type of conflict of interest that would affect the compilation of the current knowledge in this area for writing this review.

\section{REFERENCES}

1. TR Mosmann, H Cherwinski, MW Bond, MA Giedlin, RL Coffman: Two types of murine helper $\mathrm{T}$ cell clone. I. Definition according to profiles of lymphokine activities and secreted proteins. J Immunol 136(7), 2348-2357 (1986) PMid:2419430

2. AK Abbas, KM Murphy, A Sher: Functional diversity of helper T lymphocytes. Nature 383, 787-793 (1996)

DOI: $10.1038 / 383787 a 0$

PMid:8893001

3. S Constant, K Bottomly: Induction of TH1 and Th2 CD4 T cell responses: the alternative approaches. Annu Rev Immunol 15, 297-322 (1997)

DOI: 10.1146/annurev.immunol.15.1.297 PMid:9143690

4. IC Ho, D Lo, LH Glimcher: c-maf promotes T helper cell type 2 (Th2) and attenuates Th1 differentiation by both interleukin 4- dependent and -independent mechanisms. J Exp Med 
188, 1859-1866 (1998)

DOI: 10.1084/jem.188.10.1859

PMid:9815263, PMCid: PMC2212398

5. L Gorelik, PE Fields, RA Flavell: Cutting edge: TGF-beta inhibits Th type 2 development through inhibition of GATA-3 expression. $J$ Immunol 165, 4773-4777 (2000)

DOI: 10.4049/jimmunol.165.9.4773

PMid: 11045997

6. L Gorelik, S Constant, RA Flavell. Mechanism of transforming growth factor beta-induced inhibition of $\mathrm{T}$ helper type 1 differentiation. $J$ Exp Med 195, 1499-1505 (2002)

DOI: 10.1084/jem.20012076 PMid:12045248 PMCid: PMC2193549

7. W Chen, $W$ Jin, N Hardegen, KJ Lei, L Li, N Marinos, G McGrady, SM Wahl: Conversion of peripheral CD4+CD25- naive $T$ cells to CD4+ CD25+ regulatory T cells by TGF-beta induction of transcription factor Foxp3. J Exp Med 198, 1875-1886 (2003)

DOI: $10.1084 /$ jem.20030152

PMid:14676299, PMCid: PMC2194145

8. E Betteli, Y Carrier, W Gao, T Korn, TB Strom, M Oukka, HL Weiner, VK Kuchroo: Reciprocal developmental pathways for the generation of pathogenic effector $\mathrm{TH} 17$ and regulatory $\mathrm{T}$ cells. Nature 441, 235-238 (2006)

DOI: $10.1038 /$ nature 04753

PMid:16648838

9. EV Acosta-Rodriguez, G Napolitani, A Lanzavecchia, F Sallusto: Interleukins 1 beta and 6 but not transforming growth factorbeta are essential for the differentiation of interleukin 17-producing human $\mathrm{T}$ helper cells. Nat Immunol 8, 942-949 (2007)

DOI: $10.1038 /$ ni1496

PMid:17676045

10. E Betteli, T Korn, VK Kuchroo: Th17: the third member of the effector T cell trilogy. Curr Opin Immunol 19, 652-657 (2007)

DOI: 10.1016/j.coi.2007.07.020

PMid:1776609, PMCid: PMC2288775

11. II Ivanov, BS McKenie, L Zhou, CE Tadokoro, A Lepelley, JJ Lafaille, DJ Cua, DR Littman: The orphan nuclear receptor RORgammat directs the differentiation program of proinflammatory IL-17+ T helper cells. Cell 126, 1121-1133 (2006).

DOI: 10.1016/j.cell.2006.07.035

PMid:16990136
12. AN Mathur, HC Chang, DG Zisoulis, GL Stritesky, Q Yu, JT O'Malley, R Kapur, DE Levy, GS Kansas, MH Kaplan: Stat3 and Stat4 direct development of IL-17- secreting Th cells. J Immunol 178, 4901-4907 (2007).

DOI: 10.4049/jimmunol.178.8.4901

PMid:17404271

13. XO Yang, BP Pappu, R Nurieva, AAkimzhanov, HS Kang, Y Chung, L Ma, B Shah, AD Panopoulos, KS Schluns, SS Watowich, Q Tian, AM Jetten, C Dong: T helper 17 lineage differentiation is programmed by orphan nuclear receptors ROR alpha and ROR gamma. Immunity 28, 29-39 (2008)

DOI: 10.1016/j.immuni.2007.11.016

PMid:18164222, PMCid: PMC2587175

14. L Zhou, II Ivanov, R Spolski, R Min, K Shenderov, T Egawa, DE Levy, WJ Leonard, DR Littman: IL-6 programs $\mathrm{T}(\mathrm{H})-17$ cell differentiation by promoting sequential engagement of the IL-21 and IL-23 pathways. Nat Immunol 8, 967-974 (2007)

DOI: $10.1038 /$ ni1488

PMid:17581537

15. L Han, J Yang, $X$ Wang, $Q$ Wu, S Yin, Z Li, J Zhang, YXing, Z Chen, A Tsun, D Li, M Piccioni, Y Zhang, Q Guo, L Jiang, L Bao, L Lv, B Li: The E3 deubiquitinase USP17 is a positive regulator of retinoic acid-related orphan nuclear receptor $\gamma \mathrm{t}$ (ROR $\gamma \mathrm{t}$ ) in Th17 cells. J Biol Chem 289(37), 25546-25555 (2014)

DOI: 10.1074/jbc.M114.565291

PMid:25070893, PMCid: PMC4162160

16. A Lainé, B Martin, M Luka, L Mir, C Auffray, B Lucas, G Bismuth, C Charvet: Foxo1 Is a T CellIntrinsic Inhibitor of the ROR $\gamma$ t-Th17 Program. J Immunol 195(4), 1791-1803 (2015)

DOI: 10.4049/jimmunol.1500849 PMid:26170390

17. J Skepner, M Trocha, R Ramesh, XA Qu, D Schmidt, E Baloglu, M Lobera, S Davis, MA Nolan, TJ Carlson, J Hill, S Ghosh, MS Sundrud, J Yang: In vivo regulation of gene expression and Thelper type 17 differentiation by RORyt inverse agonists. Immunology 145(3), 347-256 (2015)

DOI: $10.1111 / \mathrm{imm} .12444$

PMid:25604624

18. S Xiao, N Yosef, J Yang, Y Wang, L Zhou, C Zhu, C Wu, E Baloglu, D Schmidt, R Ramesh, M Lobera, MS Sundrud, PY Tsai, Z Xiang, J 
Wang, $Y$ Xu, $X$ Lin, K Kretschmer, PB Rahl, RA Young, Z Zhong, DA Hafler, A Regev, $S$ Ghosh, A Marson, VK Kuchroo: Smallmolecule ROR $\gamma$ t antagonists inhibit $T$ helper 17 cell transcriptional network by divergent mechanisms. Immunity 40(4), 477-489 (2014) DOI: 10.1016/j.immuni.2014.04.004 PMid:24745332, PMCid: PMC4066874

19. M Ganjalikhani Hakemi, K Ghaedi, V Homayouni, A Andalib, M Hosseini, A Rezaei: Positive and Negative Regulation of Th17 Cell Differentiation: Evaluating The Impact of RORC2. Cell J 16(3), 343-352 (2014)

PMid:24611151, PMCid: PMC4204187

20. S Nakae, Y Iwakura, H Suto, SJ Galli: Phenotypic differences between Th1 and Th17 cells and negative regulation of Th1 cell differentiation by IL-17. J Leuk Bio 81, 1258-1268 (2007)

DOI: 10.1189/jlb.1006610

PMid:17307864

21. G Huang, Y Wang, $\mathrm{H}$ Chi: Regulation of Th17 cell differentiation by innate immune signals.

Cell Mol Immunol 9(4), 287-295 (2012)

DOI: $10.1038 / \mathrm{cmi} .2012 .10$

PMid:22504954, PMCid: PMC3423893

22. T Korn, E Bettelli, M Oukka, VK Kuchroo: IL-17 and Th17 Cells. Anna Rev Immunol 27, 485-517 (2009)

DOI: $\quad$ 10.1146/annurev.immunol.021908. 132710

PMid:19132915

23. A Brüstle, S Heink, M Huber, $C$ Rosenplänter, C Stadelmann, P Yu, E Arpaia, TW Mak, $T$ Kamradt, M Loboff: The development of inflammatory $\mathrm{T}(\mathrm{H})-17$ cells requires interferon-regulatory factor 4. Nat Immunol 8, 958-966 (2007)

DOI: 10.1038/ni1500

PMid:17676043

24. Q Chen, W Yang, S Gupta, P Biswas, P Smith, $G$ Bhagat, $A B$ Pernis: IRF-4-binding protein inhibits interleukin-17 and interleukin-21 production by controlling the activity of IRF-4 transcription factor. Immunity 29:(6), 899-911 (2008)

DOI: 10.1016/j.immuni.2008.10.011

PMid:19062315 PMCid: PMC2633410

25. M Huber, A Brüstle, K Reinhard, A Guralnik, G Walter, A Mahiny, E von Löw, M Lohoff: IRF4 is essential for IL-21-mediated induction, amplification, and stabilization of the Th17 phenotype. Proc Natl Acad Sci USA 105, 20846-20851 (2008)

DOI: $10.1073 /$ pnas.0809077106

PMid:19088203, PMCid: PMC2634912

26. Y Chung, SH Chang, GJ Martinez, XO Yang, R Nurieva, HS Kang, L Ma, SS Watowich, AM Jetten, Q Tian, C Dong: Critical regulation of early Th17 cell differentiation by interleukin-1 signaling. Immunity 30, 576-587 (2009)

DOI: 10.1016/j.immuni.2009.02.007

PMid:19362022, PMCid: PMC2705871

27. DR Echlin, HJ Tae, N Mitin, EJ Taparowsky: B-ATF functions as a negative regulator of AP-1 mediated transcription and blocks cellular transformation by Ras and Fos. Oncogene 19, 1752- 1763 (2000)

DOI: 10.1038/sj.onc.1203491

PMid:10777209

28. GJ Martinez, RI Nurieva, XO Yang, C Dong: Regulation and function of proinflammatory TH17 cells. Ann N Y Acad Sci 1143, 188-211 (2008)

DOI: 10.1196/annals.1443.021

PMid:19076351

29. GJ Martinez, C Dong: BATF: bringing (in) another Th17-regulating factor. $\mathrm{J} \mathrm{Mol} \mathrm{Cell} \mathrm{Biol}$ 1, 66-68 (2009)

DOI: 10.1093/jmcb/mjp016

PMid:19726487

30. BU Schraml, K Hildner, W Ise, WL Lee, WA Smith, B Solomon, G Sahota, J Sim, R Mukasa, S Cemerski, RD Hatton, GD Stormo, CT Weaver, JH Russell, TL Murphy, KM Murphy: The AP-1 transcription factor Batf controls $\mathrm{T}(\mathrm{H}) 17$ differentiation. Nature 460 , 405-409 (2009)

PMid:19578362 PMCid: PMC2716014

31. IM Djuretic, D Levanon, $V$ Negreanu, $Y$ Groner, A Rao, KM Ansel: Transcription factors T-bet and Runx3 cooperate to activate Ifng and silence II4 in T helper type 1 cells. Nat immunol 8, 145-153 (2007)

DOI: $10.1038 /$ ni1424

PMid:17195845

32. T Egawa, RE Tillman, Y Naoe, I Taniuchi, DR Littman: The role of the Runx transcription factors in thymocyte differentiation and in homeostasis of naive T cells. J Exp Med 204, 1945-1957 (2007)

DOI: $10.1084 /$ jem.20070133 
PMid:17646406 PMCid: PMC2118679

33. A Collins, DR Littman, I Taniuchi: RUNX proteins in transcription factor networks that regulate T-cell lineage choice. Nat Rev Immunol 9, 106-115 (2009)

DOI: $10.1038 /$ nri2489

PMid:19165227 PMCid: PMC4231139

34. $\mathrm{Y}$ Wang, J Godec, $\mathrm{K}$ Ben-Aissa, $\mathrm{K}$ Cui, $\mathrm{K}$ Zhao, AB Pucsek, YK Lee, CT Weaver, R Yagi, V Lazarevic: The transcription factors T-bet and Runx are required for the ontogeny of pathogenic interferon- $\gamma$-producing $T$ helper 17 cells. Immunity 40(3), 355-366 (2014)

DOI: 10.1016/j.immuni.2014.01.002

PMid:24530058 PMCid: PMC3965587

35. D Mucida, Y Park, G Kim, O Turovskaya, I Scott, M Kronenberg, H Cheroutre: Reciprocal TH17 and regulatory $\mathrm{T}$ cell differentiation mediated by retinoic acid. Science 317, 256-260 (2007)

DOI: $10.1126 /$ science. 1145697

PMid:17569825

36. M Veldhoen, K Hirota, AM Westendorf, J Buer, L Dumoutier, JC Renauld, B Stockinger: The aryl hydrocarbon receptor links TH17cell-mediated autoimmunity to environmental toxins. Nature 453, 106-109 (2008)

DOI: $10.1038 /$ nature 06881

PMid:18362914

37. FJ Quintana, AS Basso, AH Iglesias, $\mathrm{T}$ Korn, MF Farez, E Bettelli, M Caccamo, M Oukka, HL Weiner: Control of Treg and TH17 cell differentiation by the aryl hydrocarbon receptor. Nature 453, 65-71 (2008)

DOI: $10.1038 /$ nature06880

PMid:18362915

38. EV Dang, J Barbi, HY Yang, D Jinasena, H Yu, Y Zheng, Z Bordman, J Fu, Y Kim, HR Yen, W Luo, K Zeller, L Shimoda, SL Topalian, GL Semenza, CV Dang, DM Pardoll, F Pan: Control of $\mathrm{T}(\mathrm{H}) 17 / \mathrm{T}$ (reg) balance by hypoxiainducible factor 1. Cell 146, 772-784 (2011)

DOI: 10.1016/j.cell.2011.07.033

PMid:21871655 PMCid: PMC3387678

39. L Zhou, JE Lopes, MMW Chong, II Ivanov, R Min, GD Victora, Y Shen, J Du, YP Rubtsov, AY Rudensky, SF Ziegler, DR Littman: TGF-binduced Foxp3 inhibits Th17 cell differentiation by antagonizing RORct function. Nature 453, 236-241 (2008)

DOI: $10.1038 /$ nature06878
PMid:18368049 PMCid: PMC2597437

40. SJ Szabo, ST Kim, GL Costa, X Zhang, CG Fathman, LH Glimcher: A novel transcription factor, T-bet, directs Th1 lineage commitment. Cell 100l, 655-669 (2000)

DOI: 10.1016/S0092-8674(00) 80702-3

41. V Lazarevic, X Chen, JH Shim, ES Hwang, EJang, AN Bolm, M Oukka, VK Kuchroo, LH Glimcher: T-bet represses $\mathrm{T}(\mathrm{H}) 17$ differentiation by preventing Runx1-mediated activation of the gene encoding RORgammat. Nat Immunol 12I, 96-104 (2011)

DOI: $10.1038 /$ ni.1969

PMid:21151104 PMCid: PMC3077962

42. R Nurieva, $X O$ Yang, $G$ Martinez, $Y$ Zhang, AD Panopoulos, L Ma, K Schluns, Q Tian, SS Watowich, AM Jetten, C Dong: Essential autocrine regulation by IL-21 in the generation of inflammatory $T$ cells. Nature 448, 480-483 (2007)

DOI: $10.1038 /$ nature05969

PMid:17581589

43. XO Yang, AD Panopoulos, R Nurieva, SH Chang, D Wang, SS Watowich, CDong: STAT3 regulates cytokine-mediated generation of inflammatory helper T cells. J Biol Chem 282, 9358-9363 (2007)

DOI: $10.1074 / j b c . C 600321200$

PMid:17277312

44. TJ Harris, JF Grosso, HR Yen, H Xin, M Kortylewski, E Albesiano, EL Hipkiss, D Getnet, MV Goldberg, CH Maris, F Housseau, $\mathrm{H} \mathrm{Yu}$, DM Pardoll, CG Drake: Cutting edge: $A n$ in vivo requirement for STAT3 signaling in TH17 development and TH17dependent autoimmunity. J Immunol 179(7), 4313-4317 (2007)

DOI: 10.4049/jimmunol.179.7.4313

PMid:17878325

45. L Durant, WT Watford, HL Ramos, A Laurence, G Vahedi, L Wei, H Takahashi, HW Sun, Y Kanno, F Powrie, JJ O'Shea: Diverse targets of the transcription factor STAT3 contribute to $T$ cell pathogenicity and homeostasis. Immunity 32(5), 605-615 (2010)

DOI: 10.1016/j.immuni.2010.05.00

PMid:20493732 PMCid: PMC3148263

46. $F$ Chalmin, $G$ Mignot, $M$ Bruchard, $A$ Chevriaux, F Vegran, A Hichami, S Ladoire, $\checkmark$ Derangere, J Vincent, D Masson, SC Robson, G Eberl, JR' Pallandre, C Borg, B 
Ryffel, L Apetoh, C Rebe, F Ghiringhelli: Stat3 and Gfi-1 Transcription Factors Control Th17 Cell Immunosuppressive Activity via the Regulation of Ectonucleotidase Expression. Immunity 36, 362-373 (2012)

DOI: 10.1016/j.immuni.2011.12.019

PMid:22406269

47. JH Yoon, K Sudo, M Kuroda, M Kato, IK Lee, JS Han, S Nakae, T Imamura, J Kim, JH Ju, DK Kim, K Matsuzaki, M Weinstein, I Matsumoto, $\mathrm{T}$ Sumida, M Mamura: Phosphorylation status determines the opposing functions of Smad2/Smad3 as STAT3 cofactors in TH17 differentiation. Nat Commun 6, 7600 (2015)

DOI: $10.1038 /$ ncomms 8600

PMid:26194464 PMCid: PMC4518312

48. R Duhen, S Glatigny, CA Arbelaez, TC Blair, M Oukka, E Bettelli: Cutting edge: the pathogenicity of IFN-gamma-producing Th17 cells is independent of T-bet. $\mathrm{J}$ Immunol 190(9), 4478-4482 (2013)

DOI: $10.4049 /$ jimmunol.1203172

PMid:23543757 PMCid: PMC3633668

49. WT Watford, BD Hissong, JH Bream, Y Kanno, L Muul, JJ O'Shea: Signaling by IL-12 and IL-23 and the immunoregulatory roles of STAT4. Immunol Rev 202, 139-156 (2004)

DOI: 10.1111/j.0105-2896.2004.00211.x

PMid:15546391

50. Z Yao, Y Kanno, M Kerenyi, G Stephens, L Durant, WTWatford,ALaurence, GWRobinson, EM Shevach, E Moriggl, L Hennighausen, C Wu, JJ O'Shea: Nonredundant roles for Stat5a/b in directly regulating Foxp3. Blood 109(10), 4368-4375 (2007)

DOI: 10.1182/blood-2006-11-055756

PMid:17227828 PMCid: PMC1885496

51. L Klotz, S Burgdorf, I Dani, K Saijo, J Flossdorf, S Hucke, J Alferink, N Nowak, M Beyer, G Mayer, B Langhans, T Klockgether, A Waisman, G Eberl, J Schultze, M Famulok, W Kolanus, C Glass, C Kurts, PA Knolle: The nuclear receptor PPAR gamma selectively inhibits Th17 differentiation in a T cell-intrinsic fashion and suppresses CNS autoimmunity. J Exp Med 206, 2079-2089 (2009)

DOI: $10.1084 /$ jem.20082771

DOI: $10.1084 /$ jem.20082771120409c

PMid:19737866

52. B Li, JM Reynolds, RD Stout, DA Bernlohr, J Suttles: Regulation of Th17 differentiation by epidermal fatty acid-binding protein. J Immunol 182, 7625-7633 (2009)

DOI: $10.4049 /$ jimmunol.0804192

PMid:19494286 PMCid: PMC2707838

Key Words: Th17, Th17 Differentiation, RORs, IRF4, BATF, RUNX1, FOXP3, STATs, Review

Send correspondence to: Ayten Nalbant, İzmir Institute of Technology, Department of Molecular Biology and Genetics, Molecular Immunology and Gene Regulation Laboratory, Urla, İzmir, 35430 Turkey, Tel: 90232 7507317, Fax: 90232 7507303, E-mail: aytennalbant@iyte.edu.tr 